\title{
Editorial for Special Issue "Supergene Evolution of Polymetallic Deposits, Including Non-Laterite Fe and Mn Ores"
}

\author{
Maria Boni ${ }^{1, *}$ and Johan Yans ${ }^{2, *}$ \\ 1 Dipartimento Scienze della Terra, Università di Napoli “Federico II" Complesso Universitario di Monte S. \\ Angelo, Via Cinthia 26, 80126 Napoli, Italy \\ 2 Department of Geology, Institute of Life, Earth and Environment-ILEE, University of Namur, \\ 5000 Namur, Belgium \\ * Correspondence: boni@unina.it (M.B.); johan.yans@unamur.be (J.Y.)
}

check for updates

Citation: Boni, M.; Yans, J. Editorial for Special Issue “Supergene Evolution of Polymetallic Deposits, Including

Non-Laterite Fe and Mn Ores". Minerals 2021, 11, 946. https:/ / doi.org/10.3390/min11090946

Received: 20 August 2021

Accepted: 28 August 2021

Published: 30 August 2021

Publisher's Note: MDPI stays neutral with regard to jurisdictional claims in published maps and institutional affiliations.

Copyright: (c) 2021 by the authors. Licensee MDPI, Basel, Switzerland. This article is an open access article distributed under the terms and conditions of the Creative Commons Attribution (CC BY) license (https:// creativecommons.org/licenses/by/ $4.0 /)$.
This Special Issue of Minerals published 3 years after the issues on non-sulphide ore deposits [1] and bauxites [2] demonstrates that the subject of weathering-related ores is growing in both scientific and economic importance. This collection of scientific contributions was born as an ideal continuation of the previous Special Issues.

This Special Issue, "Supergene Evolution of Polymetallic Deposits, including NonLaterite Fe and Mn Ores" (Guest Editor: Prof. Dr. Maria Boni, co-Guest Editors: Prof. Dr. Giuseppina Balassone, Dr. Nicola Mondillo, Dr. Augustin Dekoninck, Prof. Dr. Johan Yans), aimed to publish studies concerning the behaviour of several metals, such as $\mathrm{Zn}$, $\mathrm{Pb}, \mathrm{Cu}$, and $\mathrm{Co}$ when subjected to secondary weathering and oxidation processes. Most of these originally occurred in primary/hypogene sulphide ores. There are several cases when the secondary metal concentrations develop economic importance, including $\mathrm{Zn}-\mathrm{Pb}$ "nonsulphides", the $\mathrm{Cu}$ supergene sulphides/oxides/carbonates on top of world-sized sulphide ore bodies, and the supergene Co enrichments from primary sulphide ores. Besides these base metals, Fe and Mn also form oxidised ores due to the high oxidation potential allowed by their trivalent and tetravalent forms. These ores gradually evolved from reducing to oxidising mineral assemblages when they encountered higher oxidation levels and various $\mathrm{pH}$ values in the upper crust.

Since the 2000s, the increasing demand for metals and rare earth elements in new technologies initiated/restarted interest in supergene deposits. The exploitation for such deposits is usually easier and faster than for hypogene ores, owing to their near-surface location and metal content being usually higher than in the primary ore. Moreover, recent advances in hydrometallurgical acid leaching, solvent extraction (SX) and electrowinning techniques facilitate post-extraction treatments for many non-sulphide ores. The studies collected in this Special Issue aim to document the main developments achieved during the last few years in many deposits, especially those located in several African countries. The African deposits have seen the birth of new concepts, new technologies, and new applications to supergene-related studies.

Three of the studies describe deposits of different sizes that have been subjected to weathering processes. The most economically valuable is the Giant Copper Deposit of Tizert (Igherm Inlier) [3], hosted by sedimentary rocks at the Ediacaran/Cambrian transition and considered the largest copper resource in the western Anti-Atlas (Morocco). Tizert resources are now estimated to be 56,820,000 $\mathrm{t}$ with $1.03 \% \mathrm{Cu}$ and $23 \mathrm{~g} / \mathrm{t} \mathrm{Ag}$. Cu mineralisation is conducted by malachite, chalcocite, covellite, bornite, and chalcopyrite, with the supergene enrichment most likely related to episodes of uplift/doming (last event since $30 \mathrm{Ma}$ ), which triggered the exhumation of the hypogene mineralisation.

A smaller deposit, consisting of hydrothermal barite/fluorite veins accompanied by moderate amounts of non-sulphides hosted by Mesozoic carbonates, has been described from the area of Bou Caiid (Ouarsenis) in Algeria [4]. The supergene minerals consist of 
hemimorphite, smithsonite, cerussite, hydrozincite, and Fe-oxy-hydroxides, with remnants of galena and sphalerite in variable proportions. The supergene enrichment at Bou Caïd is related to the uplift and fracturing of the host carbonates during the Cenozoic era.

The promising Kihabe prospect, not yet fully developed, contains $\mathrm{Zn}-$ and $\mathrm{Pb}-(+\mathrm{Cu}-$ $\mathrm{Ag}$ ) non-sulphides accompanied by variable proportions of vanadium minerals and traces of germanium in the Aha Hills region (North-Western Botswana) and was studied by Mondillo et al. [5]. Kihabe is hosted in a strongly deformed Proterozoic fold belt, corresponding to the NE extension of the Namibian Damara Orogen. Among the non-sulphide assemblage, two styles of mineralisation occur: the first one was characterised by hydrothermal willemite and fraipontite/baileychlore, and the second one consists of supergene smithsonite, cerussite, hemimorphite, $\mathrm{Pb}$-phosphates, arsenates, and vanadates. The weathering likely occurred in this part of Botswana (as in the Otavi Mountain Land in Namibia) from the Late Cretaceous to Miocene. In these three deposits of different sizes, secondary $\mathrm{Cu}-\mathrm{Pb}-\mathrm{Zn}-\mathrm{V}-\mathrm{Ag}$ minerals result from the rapid neutralization by host carbonates of acidic meteoric fluids due to oxidation of primary sulphides.

The study on the Touissit-Bou Beker and Jbel Bou Dahar (Morocco) supergene ores [6] is considered the feature article of this issue for its interesting content and well-argued conclusions. The Moroccan Atlas system's world-class Mississippi Valley-type districts have been investigated by integrating $\mathrm{Pb}-\mathrm{Zn} \pm \mathrm{Cu}$ mineralogy, texture, and stable isotope $(\mathrm{C}, \mathrm{O}, \mathrm{S})$ geochemistry. Stable isotope compositions $\left(\delta^{13} \mathrm{C}_{\mathrm{V}-\mathrm{PDB}}, \delta^{18} \mathrm{O}_{\mathrm{V}-\mathrm{SMOW}}, \delta^{34} \mathrm{~S}_{\mathrm{CDT}}\right)$ support a three-stage model whereby metals were released by supergene acidic fluids and then precipitated by bacteria and archaea-mediated metal-rich meteoric fluids due to a decrease in temperature and/or increase of $f \mathrm{O}_{2}$. Oxygen isotope thermometry indicates decreasing precipitation temperatures with an advancing paragenetic sequence from $33^{\circ} \mathrm{C}$ to $18^{\circ} \mathrm{C}$ under wet to semi-arid to arid climatic conditions. On the whole, the involvement of biologically controlled activity was shown for the first time as the major driving process that triggered both oxidation and deposition of supergene mineralisation in a period after the main stage of the Alpine orogeny between $15 \mathrm{Ma}$ and the present.

The Special Issue is completed by two more methodological studies [7,8]. Yans et al. [7] obtained (U-Th)/He ages on supergene goethite from various Fe deposits of the NefzaSejnane district in Tunisia. The results directly date significant weathering episodes in this area during the late Tortonian and late Pleistocene. These data, matched with previous works, refine the stratigraphic frame for the polymetallic mineralisation in the district, confirming the influence of meteoric regional scale circulation of fluids during the late Cenozoic. Santoro et al. [8] provide a comprehensive assessment of the trace element fingerprint of $\mathrm{FeO} / \mathrm{OH}$ in many $\mathrm{Zn}$ non-sulphide deposits. The Fe-oxy-hydroxides are rarely pure since they form in systems where a wide range of metals, most of them with economic importance (e.g., $\mathrm{Zn}, \mathrm{Pb}, \mathrm{Co}, \mathrm{REE}, \mathrm{Sc}, \mathrm{Ga}, \mathrm{Ge}, \mathrm{V}$, etc.), freely circulate and can be "captured" under specific conditions. To achieve a better knowledge of the controlling parameters, $\mathrm{FeO} / \mathrm{OH}$-bearing mineralised samples were selected from several $\mathrm{Zn}$ nonsulphide ores in diverse settings: Hakkari (Turkey), Jabali (Yemen), Cristal (Peru), Kabwe (Zambia), and investigated with different methods.

These contributions improve our knowledge of the supergene processes (involving $\mathrm{pH}$, Eh, the role of the host rocks and bacterial activity, types of fluids, and more) and the timing of weathering that generates polymetallic supergene ores. An important area of new research will unravel the potential contribution(s) of biotic components during the weathering of primary ores. This new research will be especially challenging for ancient supergene weathering.

Author Contributions: Conceptualization, M.B. and J.Y.; original draft preparation, M.B and J.Y.; review and editing, J.Y.; supervision, M.B. Both authors have read and agreed to the published version of the manuscript.

Conflicts of Interest: The authors declare no conflict of interest. 


\section{References}

1. Boni, M. Home Page of Special Issue "Geology and Mineralogy of Zn-Pb Nonsulfide Deposits". Available online: https: //www.mdpi.com/journal/minerals/special_issues/nonsulfide_deposits (accessed on 19 August 2021).

2. Oggiano, G. Home Page of Special Issue "Bauxite Deposits". Available online: https://www.mdpi.com/journal/minerals/ special_issues/bauxite_deposits (accessed on 19 August 2021).

3. Poot, J.; Verhaert, M.; Dekoninck, A.; Oummouch, A.; El Basbas, A.; Maacha, L.; Yans, J. Characterization of Weathering Pro-cesses of the Giant Copper Deposit of Tizert (Igherm Inlier, Anti-Atlas, Morocco). Minerals 2020, 10, 620. [CrossRef]

4. Louha, H.; Balassone, G.; Boutaleb, A.; Boni, M.; Joachimski, M.M.; Mondillo, N. The Pb-Zn (Ba) Nonsulfide Minerali-zations at Bou Caïd (Ouarsenis, Algeria): Mineralogy, Isotope Geochemistry, and Genetic Inferences. Minerals 2021, 11, 687. [CrossRef]

5. Mondillo, N.; Boni, M.; Balassone, G.; Forrester, N.; Putzolu, F.; Santoro, L. Mineralogy and Genesis of the Kihabe Zn-Pb-V Prospect, Aha Hills, Northwest Botswana. Minerals 2020, 10, 685. [CrossRef]

6. Bouabdellah, M.; Boukirou, W.; Potra, A.; Melchiorre, E.; Bouzahzah, H.; Yans, J.; Zaid, K.; Idbaroud, M.; Poot, J.; Dekoninck, A. Origin of the Moroccan Touissit-Bou Beker and Jbel Bou Dahar Supergene Non-Sulfide Biominerali-zation and Its Relevance to Microbiological Activity, Late Miocene Uplift and Climate Changes. Minerals 2021, 11, 401. [CrossRef]

7. Yans, J.; Verhaert, M.; Gautheron, C.; Antoine, P.-O.; Moussi, B.; Dekoninck, A.; Decrée, S.; Chaftar, H.-R.; Hatira, N.; Dupuis, C. (U-Th)/He Dating of Supergene Iron (Oxyhydr-)Oxides of the Nefza-Sejnane District (Tuni-sia): New Insights into Mineralization and Mammalian Biostratigraphy. Minerals 2021, 11, 260. [CrossRef]

8. Santoro, L.; Putzolu, F.; Mondillo, N.; Boni, M.; Herrington, R. Influence of Genetic Processes on Geochemistry of Fe-oxyhydroxides in Supergene Zn Non-Sulfide Deposits. Minerals 2020, 10, 602. [CrossRef] 